Document downloaded from:

http://hdl.handle.net/10251/135017

This paper must be cited as:

Diodato, M.; Macchioni, N.; Brunetti, M.; Pizzo, B.; Nocetti, M.; Burato, P.; Sozzi, L.... (2015). Understanding Spanish Timber Jack Arch Floors: Examples of Assessment and Conservation Issues. International Journal of Architectural Heritage. 9(6):641-654. https://doi.org/10.1080/15583058.2015.1041193

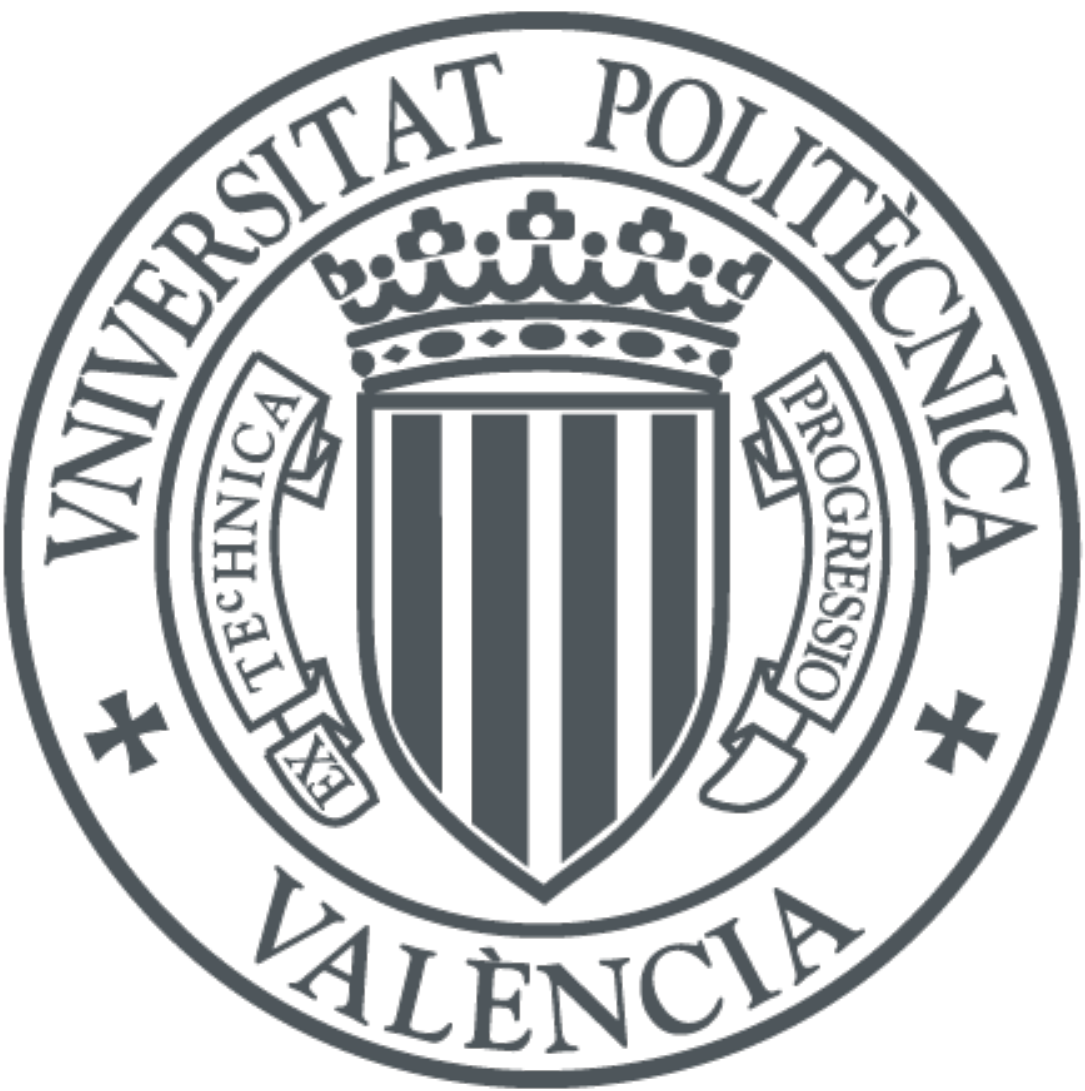

The final publication is available at

http://dx.doi.org/10.1080/15583058.2015.1041193

Copyright Taylor \& Francis

Additional Information 


\title{
UNDERSTANDING SPANISH TIMBER JACK ARCH FLOORS, EXAMPLES OF ASSESSMENT AND CONSERVATION ISSUES
}

\section{Authors:}

Maria Diodato $^{\mathbf{1 a}}$, Nicola Macchioni ${ }^{2 \mathbf{b}}$, Michele Brunetti ${ }^{2 \mathbf{c}}$, Benedetto Pizzo ${ }^{2 \mathbf{d}}$, Michela Nocetti $^{2 \mathbf{e}}$, Paolo Burato ${ }^{2 f}$, Lorena Sozzi ${ }^{2 \mathbf{g}}$, Elisa Pecoraro ${ }^{2 \mathbf{h}}$, Fernando Vegas LópezManzanares $^{1 \mathbf{i}}$ and Camilla Mileto ${ }^{\mathbf{j}}$

\author{
Affiliations: \\ ${ }^{1}$ Instituto de Restauración del Patrimonio, Universitat Politècnica de València, Edificio 8B, \\ Acceso L, Nivel 0, Camino de Vera s/n - 46022 Valencia, Spain \\ ${ }^{2}$ CNR-IVALSA, Istituto per la valorizzazione del legno e delle specie arboree, Consiglio \\ Nazionale delle Ricerche, via Madonna del Piano, 10 - 50019 Sesto Fiorentino (FI), Italy \\ Telephone numbers and e-mails: \\ a 0034670336746 m.diodato@hotmail.com, b00393355425776 macchioni@ivalsa.cnr.it, \\ c00390555225627 brunetti@ivalsa.cnr.it, d00390555225623 pizzo@ivalsa.cnr.it, \\ e00390555225754 nocetti@ivalsa.cnr.it, f 00390555225628 burato@ivalsa.cnr.it, \\ g00390555225687 sozzi@ivalsa.cnr.it, ho0390555225505 pecoraro@ivalsa.cnr.it, \\ i 0034963877971 fvegas@cpa.upv.es, ${ }^{j} 0034963877971$ cami2@cpa.upv.es
}

\begin{abstract}
:
Jack arch floors are structures made of timber joists, with round or squared section, and segmental vaults either made of flat tiles or poured plaster conglomerate. They are especially diffused along the Mediterranean coast of Spain and can be considered as a main feature of the historical and vernacular architecture of the area. In order to assess and grade these structures several Spanish standards have been considered; however, even if the information contained is useful the Italian standard for the on-site diagnosis UNI 11119 of 2004 has been preferred. The method described in this standard leads the assessment through the grading of each and every timber element and the assignation of bearing properties that are essential for the consolidation project. This article will expose three examples of jack arch floors of the Valencian Community graded using the Italian standard and the conservation issues that arise from the results.
\end{abstract}

Keywords:

Jack arch floor, timber, grading, on-site assessment, UNI 11119, Valencian Community. 


\section{INTRODUCTION}

The research about traditional timber structures and their features is exceptionally significant because of its repercussion on nowadays questions. Not only the increased knowledge about traditional buildings make it possible to learn lessons for today's architecture, but also the analytical effort of the research has a direct relation with the importance and value that is generally attributed to the structures and their conservation.

Starting with the historic research, the typological and constructive analysis, the structural grading and the on-site assessment of an existing timber structure are the basis of its conservation. The first two activities promote this conservation while the second two gives the means to achieve it because they realistically quantify the real geometry of the members composing the structure and their residual load-bearing capacity. Without this information being known the structure would be less likely preserved.

These considerations affect mostly minor and not decorated structures that do not inspire the need for conservation for themselves unlike the remarkable and ornamented ceilings and roofs that may be found in public buildings. One of these minor types of structures is the jack arch floor (forjado de revoltones, in Spanish, plancher à voûtains, in French, solaio con voltine di mattoni, in Italian), which is composed by a sequence of joists that support small segmental barrel vaults. Jack arch floors are very common and specific of the eastern coast of Spain, especially with traditional timber joists, while the newer version with iron beams is diffuse also in France, Italy and England.

This type of floors represents a local variety of great relevance and, therefore, constitutes a component of the local cultural heritage that should be preserved as much as possible, without unnecessary changes. However, in Spain this kind of structures are not generally considered an important characteristic of the buildings and for this reason it is a common practice to systematically replace them. This substitution is caused by the unfamiliarity of the designers 
with old timber structures as well as by the widespread habit to "restore" a building demolishing completely the interior and keeping only the façade which is, in many cases, the only legal restriction for conservation.

A contributing factor to this misconduct is that in Spain there is not a formal and widespread method to assess timber structures, so even the architects that would like to undertake a conservative path are discouraged by the lack of means. For this reason, the attempts made to apply the Italian standard UNI 11119 of 2004 "On-site inspections for the diagnosis of timber members" to jack arch floors can be significant as they may encourage the implementation of a proper method of assessing timber.

The examples taken into consideration here for the description of the technique and the case study are located in the Valencian Community where this structural feature is extremely diffused both in urban and rural vernacular buildings since the beginning of the $16^{\text {th }}$ century.

\section{JACK ARCH FLOORS}

\subsection{Early examples of jack arch floors}

In the Valencian region, the first mention of what can be considered a jack arch floor seems to concern the works of the House of the Provincial Council in 1481: "cuberta de cabiros ab volta" (Gómez-Ferrer Lozano, 2002, p. 93). Around the beginning of the $16^{\text {th }}$ century this kind of floors started to proliferate around Valencia where the first documented mention of painted jack arch floors is the restoration of the so-called Sala Dorada of the Palacio Real in 1501, information cited in the contract for the decoration of the Valencian house of the Bishop of Tortosa in 1502 (Gómez-Ferrer Lozano et al., 2004. pp. 11-31). From the same period and similar appearance was also the hall's ceiling of the Palace of the Centelles family 
in Oliva (VV. AA., 1997), which presented a beautiful frieze depicting a military parade, as can be seen in old pictures (Figure 1).

The mentioned palaces were of great significance at the time and the decision of building that type of floors indicates that they were considered a decorative novelty and a structural innovation worth placing in such important spaces. Outside the Valencian Community, a contemporary and still existing example is the ceiling of the main staircase of the Aljafería Palace in Zaragoza, residence of the Catholic Monarchs of the Kingdom of Aragon who renovated those wings of the palace between 1488 and 1495 (Figure 2).

Figure 1.

Figure 2.

While the earliest documented examples of jack arch floor date from the end of the $15^{\text {th }}$ century and the beginning of the $16^{\text {th }}$ century, its diffusion throughout the Valencian Community took place mostly from the $18^{\text {th }}$ century probably because of the scarcity of wood that the region was experiencing. All of jack arch floor variants are characterized by an unsophisticated construction process and a reduced use of timber consistent with the situation of limited wood supply.

\subsection{General configuration of the structure}

As a general description, the jack arch floor structure consists of a sequence of joists separated by longitudinal segmental timbrel vaults. There are however a number of different variations to this construction technique that are partially related to the evolution of the industrialization. Therefore, in rural areas, where there was no access to sawmills or 
brickworks, the structures were generally built with round wood as joists and plaster conglomerate vaults, while squared beams combined with brick vaults were more common in urban areas, even in small towns. As a confirmation, in the city of Valencia no structures of the first type have been discovered. Finally in modern eras the timber joists have been substituted by iron girders or concrete beams (Diodato, 2015).

Analyzing separately the different parts of the structure will ensure the understanding of all the different existing morphologies of the structure (Figure 3).

Commencing with the overall configuration, the joists' ends are generally placed inside the walls while constructing or renovating the building, the design is always quite plain with no secondary structure or brackets and plates supporting the joists. In a number of cases the structure has two spans and covers two connected inner spaces, so one end of each joist rests on a central main beam. The floor's joist spacing, i.e. the distance between the centers of any two installed joists, usually fluctuates around $60-70 \mathrm{~cm}$ but in case of big squared joists or iron girders located in urban areas it can be more than $1 \mathrm{~m}$. In contrast, it is not common to see reduced spacings in the studied area because one of the main points in favor of this kind of construction is the moderated use of timber, and if the spacing is reduced the consumption of timber would increase. However, there is a tendency of reducing the section of the joist as well as the spacing during the centuries changing the configuration of the structure from big solid beams and large spacing to a greater number of smaller and often composed joists with minor spacing. Even so it is not a strict rule as it is possible to find spacings larger than $1 \mathrm{~m}$ in distinguished buildings of the $19^{\text {th }}$ century, such as the Real Colegio Seminario del Corpus Christi also called "Colegio del Patriarca" in Valencia.

Figure 3. 


\subsection{Main structural element: the joists}

The joists used in jack arch floors can have different shapes.

The most basic kind of joist is the bare trunk of a tree, simply debarked. In this case the bark is peeled and the branches cut so that on the surface it is possible to clearly see knots and grain. Usually the upper surface of these round joists is hit with a small hatchet in order to produce carvings that would improve the grip of the vaults, normally made of plaster conglomerate. The bottom exposed surface is generally coarse; however, at times these joists are smoothed or sanded to improve their appearance and in very few cases small longitudinal recesses are carved along the joist as a sort of decoration. This variant of joists is widely diffused in all kind of rural buildings and in houses located in small towns. Occasionally, because of the poor knowledge and skills of the constructors, they do not cut off the bark from the trunks before using them or they select twisted elements, unfitted for construction, producing unfortunate structures (Figure 4).

Figure 4.

The second main type of joist is more elaborate than the previous one because it generally employs sawed elements. These joists are made of squared timber with an approximately rectangular section whose base varies from 15 to $35 \mathrm{~cm}$ although the most common sizes are around $19 \mathrm{~cm}$ and $30 \mathrm{~cm}$. These joists have two carved notches along their lateral faces in order to better sustain the vaults. These indentations reduce somehow the section of the load bearing elements but are essential for the correct construction of the jack arch floor.

This type of joists is the oldest solution and has been used from the beginnings until the $20^{\text {th }}$ century. However a very common and more recent alternative for these joists is composed by three parts: a central piece of sawed timber and two side battens nailed like wings creating a 
reversed $\mathrm{T}$ section. The nails, which are placed along the entire length of the element every 10 or $20 \mathrm{~cm}$, are not positioned all on the same line but have two different heights forming a zigzag and avoiding weakening the battens in the same horizontal plane. This solution was diffused with the industrialization when the price of the metal elements such as nails diminished while increased the price of wood. The base of the section of these joists is 15$20 \mathrm{~cm}$, smaller than the previous one.

Both the joists with the notches and the composed ones proliferated from the second half of the $19^{\text {th }}$ century and can be found either with coarse surfaces or smoothed and sanded. The only kind of decoration present on the timber is applied along the two visible edges of the joists where a three-quarter or one-quarter molding is carved.

Decorated with moldings or not, sometimes, the structures remain hidden behind false ceilings by design or due to a change in fashion (Figure 5). These false ceilings are made of a plaster finishing and panels of reeds tied together and nailed to the joists or to a hanging timber frame. Nowadays, after some restorations, these joists are frequently brought to light.

\section{Figure 5.}

The types of joists described until now, the round and squared ones, cover the vast majority of the existing structures; however there are two other rare variants to this scheme.

The first is a variant of the squared beam composed by three pieces. In this case, the battens are not nailed at the same level of the intrados increasing the base of the section; instead they are nailed in the middle of the two lateral faces of the joist. This solution establishes a change in the geometry of the section and might have been necessary to guarantee the horizontality of the vaults if the joists were deflected or if they were not put perfectly horizontal. 
The second peculiar solution of jack arch floors is especially decorative and distinctive. The joists, in this case, have a square section and are put in place with a rotation of $45^{\circ}$. This morphology is practical also from the constructive point of view because the timber elements do not need to be carved to hold the vaults. However the masonry around the ends of the joists, where they rest inside the wall, had to be organized properly. The three visible edges of the joists may also be carved with a three-quarter molding.

With the introduction of new and industrial materials, also the jack arch floors adapted to new trends by replacing progressively timber joists with iron elements. With this new material jack arch floors spread even more because, due to the curved geometry they allowed large joist spacings and, compared to other solutions, reduced the number of the expensive iron elements. The joists used to be I-shaped cross-section girders with a base of $10 \mathrm{~cm}$; they were used in all kind of buildings, often combined with cast iron columns in Neo-Doric style and planar trusses as main beams.

In even more recent times precast concrete beams have been introduced maintaining the same construction technique.

\subsection{Secondary structural element: the barrel vaults}

The second element that together with the joists generates the jack arch floors is the vault.

Barrel vaults, to them relate the Spanish term revoltón, occupy the spaces between the joists and are supported by them. The geometry of the vaults is quite variable although almost always is segmental and only in rare cases it comes near to a semicircular arch; in the majority of the cases the ratio between the span and the rise of the arch is between 3.5 and 5 , however there are also samples whose ratio is bigger, reducing in this way the advantages of a vaulted structure because of their shallow curvature. 
The height of the joist's section, the spacing between joists and the geometry of the vaults are closely related. The extrados of the vault and the upper face of the joists are usually more or less coplanar (Figure 6). In this way, the amount of filling that configures a smooth surface suitable to accommodate a pavement on top of the structural elements is small. If the coplanar condition is not respected the filling and the total weight of the structure would be greater. For this reason the tendency is that bigger spans are consistent with proportionally smaller arch rises and square joists' section.

Figure 6.

Passing from the geometry to the constructive aspect of the vaults, the main construction techniques are two (Figure 7).

The first kind of vaults is built with plaster conglomerate. The construction process starts by securing a formwork made of timber boards between two joists; afterwards the plaster conglomerate is poured on top of the formwork from above and leveled with the extrados of the joists. Inside the conglomerate, flat stones, pieces of brick or tiles reinforce the vault. After the conglomerate consolidates, the formwork is removed and place in the next space between joists while the pattern of the boards is left engraved on the intrados surface. One rare variant is to substitute the timber formwork with a structure of reeds which would leave deeper marks on the surface of the intrados, which afterwards would have been plastered from underneath.

The plaster conglomerate vault is typically associated with round joists and, in order to improve the grip between the two elements, either long reeds are nailed laterally to the joists before pouring the filling conglomerate or marks are made with a hatchet on the surface of the joists. 
This construction technique is typical of rural areas where the access to bricks was limited; on the contrary, in urban areas timbrel vaults are generally made with solid bricks approximately 2-3 cm thick arranged lengthwise and put together with fast-setting plaster mortar. For the construction of these vaults no stationary centering is usually employed, only a mobile guide to maintain the shape of the vault. Depending on the spacing of the joists a different number of bricks are needed to complete an arch and when necessary half brick is used as key. The space on top of the vault is generally filled with plaster conglomerate or with compacted earth.

Although some treatises describes vaults made with rowlock courses of bricks or two layer of bricks, the structures studied in the Valencian Community usually are built with just one layer of bricks and sometimes another line of ceramic elements on top of the impost of the vaults to improve their stability.

Figure 7.

In proportion only few jack arch floors are decorated because these structures are mainly built in popular constructions where there is no need or budget to improve the aesthetic appeal. However, when decorated, three are the main techniques (Figure 8); all of these decorative layers are applied only to the vaults so that the grain of the timber joists remains visible even if the wood is decoratively carved as mentioned earlier.

First, tempera is used to paint floral motifs on the intrados of the vaults. Second, with the sgraffito technique, bluish stripes are created following the geometry of the structure. Third, the most impressive, modular plaster reliefs representing figures of warriors, crowns, volutes, garlands and cornucopias cover the intrados of the vault. 
Figure 8.

\subsection{Jack arch floors in the treaties}

The jack arch floor construction technique, because and despite its dissemination, was not collected in many treaties (Figure 9). This could be because the technique was used only in a part of the Iberian Peninsula while in others, the abundance of wood and the ease of building timber frameworks caused the diffusion of more complex and interesting structures as coffered ceilings and trusses. Moreover, concerning the subjects presented in these treaties, they usually gravitate around two main topics: the general rules and methods of geometry and complex or exceptional structures, both timber and masonry, which were not known to all workers.

Some of the first drawings of jack arch floors very similar to the structures that is possible to come across in the Valencian Community can be found in $19^{\text {th }}$ century treaties like the Arte de albañilería of Juan de Villanueva (Villanueva, 1827, tab. IX, pp. 59-61) where the author describes a jack arch floor made of plaster conglomerate, a sort of formwork to build the vault as well as the false ceiling made of reeds and plaster.

Only at the end of the century the literature began to produce a codification of the different structures of jack arch floors as in Carpinteria antigua y moderna of Federico de Arias y Scala (De Arias y Scala, 1897, pp. 173-174, tab. 104) or Tratado de Construccion civil of Florencio Ger y Lobez (Ger y Lobez, 1898, tab. XVI) where for the first time appeared the main variants of the jack arch floors altogether.

More diffuse is the information about the jack arch floors with iron joists collected in treaties and manuals; this is because the proliferation of writings and the dissemination of new techniques using iron went hand in hand. In some of these more modern representations of the 
technique, traditional solid bricks were replaced by more modern hollow bricks with different geometries (Chapron, 1860, pp. 115-136, tab. 42-44).

Occasionally in these drawings, there are some differences with what has been observed in the Valencian Community, for example in many drawings the vault is composed by rowlock courses of bricks whereas real structures have only one layer of bricks.

Regarding more peculiar structures such as jack arch floors with rotated square joists, the interest of writers and architects was higher as their representation was included in several treaties starting with a description by Viollet le Duc of a structure in Chartres (Viollet-le-Duc, 1854-1868, vol. 7, p. 205).

Figure 9.

\subsection{Structural configuration}

The study of the historical and constructive features of jack arch floors aims to the preservation of these structures through conservation projects that could be based on the structural assessment of their main timber elements. For this reason, it is appropriate to take into consideration the structural configuration of jack arch floors considering as well the transmission of loads.

The main structure is a series of simply supported elements with an evenly distributed load. This load comes directly from the material on top of the joists as well as from of the filling and the flooring over the barrel vaults which convey the weight to the timber elements according to their function as secondary structure.

Thanks to the geometry of the segmental barrel vault, the vector of the loads is tilted and displaced towards the joists. This tilted vector can be decomposed into two orthogonal ones, one horizontal and one vertical. While the vertical component of the forces has to be 
supported by the main structure, the horizontal component is compensated with an opposite one that comes from the adjacent vault. The lower is the vault, the bigger will be the horizontal component of the load and the smaller the vertical one. However, a lower geometry has a more delicate balance of the forces that, if modified, would result in visible cracks.

\section{JACK ARCH FLOORS PATHOLOGY}

Jack arch floors can show a number of problems due to pathological processes inherent to the two groups of structural elements: joists and vaults.

The most common issue concerning the timber is the attack from biotic decay agents (Vegas López-Manzanares and Mileto, 2011).

First of all, in the large collection of possible wood decays, the most dangerous is the attack of termites. Because of the climate of the Valencian Community the insects of the order Isoptera, and especially the species Kalotermes flavicollis y Retuculitermes lucifugus, are endemic and their wood boring work can be problematic for all kind of timber structures. These social insects, which keep away from the sunlight, usually access to the structure through the joists' ends that are inserted inside the masonry and afterwards they eat the wood along the entire elements, mostly the portions with higher moisture content. In the case of jack arch floors, in addition to the mentioned critical entry point, the termites live also along the surface between the timber and the vaults (Figure 10). This area, shielded from light and air, guarantees a safe passage through the whole joist and often it is also the softer part of the wood as it may correspond to the sapwood.

The presence of termites usually remains hidden but sometimes can be easily identified by the presence of the galleries that the insects build along the walls in order to protect themselves from the atmospheric elements when moving from the nest to the feeding areas. 
Figure 10.

The other factor causing the decay of timber is the presence of moisture usually caused by the capillary action within the walls or infiltrations. Wood is a highly hygroscopic material so the contact of the joists with bricks and plaster that are also hygroscopic, can facilitate the transmission of moisture, making the wood even more appealing for the termites. However, the real problem is that moisture content (more than 20\%) is the key factor for the proliferation of fungal attacks that cause the wood to rot. Also in this case, for the jack arch floors the danger is double because, in addition to the masonry around the joists' ends, also the vaults can transmit the moisture increasing the portion of wood exposed to degradation.

The mentioned decays may cause a severe damage to the structure and a drastic reduction of the joist's section. As both termites and rot usually develop in concealed areas characterized by high moisture content, a thorough inspection is necessary to detect these problems because not always is possible to foresee how they will affect the structure (Figure 11).

Throughout the vaulted structure, especially in the case of plaster vaults, the forces distribute peculiarly, and it cannot be predicted how the structure will respond to a significant decrease of the joists' section. Even if the severe damage would need to be repaired, sometimes the structure collapses and sometimes stands confirming the structural properties of plaster (Vegas et al., 2013) and meaning that there might be no external visible indicators of the pathological process acting on the timber, therefore underlining once more the importance of a close inspection.

Figure 11. 
Finally, the joists may have a more or less relevant attack of wood boring insects, of the family of Anobiidae from the Coleoptera order and/or of the families of the Cerambycidae and Curculionida, but a part from a superficial reduction of one or few centimeters, these do not usually represent a problem for the structure if not in combination with other decays as frequently their attacks are not ongoing. Moreover, the superficial deterioration caused by their attack and detectable through the observation of the numerous holes on the surface of the wood, is often greatly overestimated; on the contrary the hidden damage caused by rot or termites can be dangerously underestimate as they are undetectable by a superficial untrained overview.

Concerning the specific pathology of the vaults, various types of cracks can be registered.

Like all vault and arch structures, jack arch floors may experience small longitudinal cracks in correspondence to the key of the vault, especially in the case of masonry structures. These longitudinal cracks tend to open downwards because the horizontal forces are not perfectly balanced (see subchapter 2.6). This can happen due to small horizontal movements related to differential settlements or because joists, changing their moisture rate, suffer a variation in their dimensions.

Moreover, when new timber joists are placed in a structural position before being dry enough, in time, they acquire a deformation due both to shrinkage and creep. This deformation causes several transverse cracks along the barrel vault. These cracks open downwards as a result of the bending displacement of the beam, especially in its central area.

The mentioned types of cracks are not the main structural problems of the jack arch floors but they can be indicators of deeper problems concerning the timber. In fact, collapse dynamics tend mainly to be tied to the presence of termites and rot that drastically reduces the joists' section rather than to the damage of vaults. In ruinous and abandoned buildings without roof it is possible to see that, when the perimeter walls do not fail, the decay of the joists' ends is 
usually the cause of the collapse because the reduced section of wood near the wall is not enough to tolerate the shear stress. Furthermore, when moisture is absorbed by the plaster vaults they become heavier and their mechanical properties are partially reduced triggering the disintegration and collapse of the vaults.

Only in few cases the collapse of a joist happens in the middle third, usually associated with wood defects and in combination to the increase of loads or the reduction of section.

Finally it is appropriate to recall that the Valencian Community has a low value of seismic risk because, in the case of an earthquake, none of the types of structure described has the appropriate features to resist.

\section{STANDARDS AND ON SITE ASSESSMENT}

Considered the diffusion of the jack arch floors in the Valencian Community, they tend not to be considered elements of value that need preservation and therefore they are being systematically replaced by concrete slabs of contemporary design. But also when, in the case of important decorated timber floors (Delgado Martínez, 2003), architects and researchers make an effort to understand the structure, they do not usually systematize the process of knowledge to every single supporting element. The fundamental problem of this practice is that it is impossible to extrapolate, from one joist to another, either the mechanical properties or the service life of the timber elements; besides the random extent and location of the biotic attacks increase the difference between consecutive joists. To add more variability, in vernacular buildings where the materials used are the ones found near the construction site, elements from different species have been used with the same structural function. Said so, it is clear that a superficial observation from a distance is not sufficient to understand the structure. 
The common practice in the Valencian Community is to inspect and study only the few elements that at a first glance apparently create some concern. The assessment is done through different and non-standardized methods such as ultrasonic technique, ground penetrating radar, resistance drilling, screw resistance testing, screw-extraction-force tool, pilodyn and others. In several cases these procedures aim to find the density of the wood through punctual measurement. The density of the wood obtained with these tests is related with its ideal strength but the singularities along the timber element that influence its actual resistance are not taken into account.

The absence of a common procedure to assess timber structures and the underestimation of the singularities of wood is a shortcoming produced also by the structure of the Spanish standards related to timber assessment.

The Spanish standard concerning the assessment of existing buildings is UNE 41805 of 2009, "Building diagnosis. Part 1: General"; in its foreword introduces the concept of the need and purpose of conservation and concludes that the objective of any intervention is the conservation of the construction in order to restore its historical and artistic values. Within this frame is postulated the need for assessment.

The standard quotes: "In order to evaluate the damage, a proper diagnosis needs instrumental methods to scan and monitor. Moreover, in case of buildings with great historical, cultural, documentary and landscape significance, the study has to be completed with historical and constructive information, and the pathological processes identified, so that it can lead to a diagnosis that allows the selection of a reliable intervention. In the end, the result of the assessment will be the basis and justification of the intervention nature."

The section on the assessment of timber structures is "Part 8: Pathological study of the structure of the building. Wood structures". The text defines the most common structural types and features, the different problems that can arise in such elements and if these 
problems are due to the decay of the material or to structural damages caused in turn by errors in the design, execution, accidental incidents or bad interventions.

The short explanation in the standard states that for the assessment the followings are considered conventional techniques: visual examinations (unspecified), moisture meters, wood awls to check for superficial rotting and hammers; endoscopic techniques are necessary in the case of double board floors.

The following paragraph of the standard lists "new" non-destructive techniques of evaluation, which are: ultrasonic transmission, induced vibrations, resistographic drills, pilodyn and acoustic detection of wood boring insects. With the exception of the last one, according to the text, the main purpose of these techniques is to find the superficial density of the wood and the modulus of elasticity of the studied element and therefore classify it.

Despite having a description of the main singularities of the wood as the alterations and growth defects the standard does not establish any specific technique to assess the impact of these elements on the structural performance of the timber piece. However, the text mentions the possibility of applying a visual classification also for on-site timber elements.

The standards concerning explicitly with visual grading in Spain are the 2011 standard UNE 56544 and the 2013 standard UNE 56546, respectively dealing with softwood and hardwood species. Both of them are not specific for on-site assessment and refer to square edge sawn timber. They report the wood characteristics to be measured, the way to measure them and the grading rules, i.e. the limitations for the strength reducing characteristics which a piece of timber need to comply to be allocated in a visual grade.

The strength properties of the visually graded timber can be derived from two European standards: EN 1912 and EN 338. The first one lists the relationship between visual grades and strength classes for the majority of national standards on visual grading; the mechanical properties of the strength classes are then described in the EN 338. At time of writing, for 
elements with a base larger than 60-70 mm, the only assignments of Spanish timber which can be found in the standard EN 1912 are Scots pine and black pine (C22) and eucalyptus (D40).

Even if the wood peculiarities, the deformation and the biological degradation of the piece are taken into account in the Spanish standard for visual grading, the limitations refers to "new" timber, to be commercialized, and the strength characteristics derived from these visual grades cannot be easily transferred to on-site assessment.

The need of a practical tool to assess and grade on-site timber structures is relevant in the sector of architectural heritage and its conservation (Macchioni, 1998, pp. 149-162). A standard that could be used as the base for the restoration process is very much needed and the Italian standard UNI 11119 of 2004 "Cultural heritage. Wooden artefacts. Load-bearing structures - On site inspections for the diagnosis of timber members" can be the solution (Macchioni and Piazza, 2009, pp. 349-353).

Through nondestructive techniques and testing, the Italian standard describes applicable onsite procedures and criteria to assess the conservation status and the performance of timber structural elements. According to the text the assessment is made during an on-site inspection which objectives are: the determination of the wood species, the moisture content, the biological risk, the geometry and morphology of the element including the main defects, degradations and damages, the delimitation of critical areas and sections and finally the grading according to the strength of the element (Figure 12).

This standard is drafted specifically for historic wood but it mentions the possibility of using other standards with specific characteristics like the UNI 11035 of 2010 "Structural timber. Visual strength grading for structural timbers", the Italian national standard for visual grading of structural timber. 
The standard clearly states that each element of wood has to be accessible, clean and lit to optimize the inspection.

To go through the on-site grading the text describes how to measure each parameter of the considered singularities of wood which are: waney edges, checks, ring shakes, knots and grain deviation. The standard concludes with the directives about how to write the final report where should be included for example, the impossibility to access to 3 sides of the beam which is the case of jack arch floors.

Based on the measured singularities of the wood each structural element is assigned to a strength category. There are three categories and the elements which, for one or more features do not comply with the limitations of the standard will be considered not suitable for structural use. A table at the end of the standard relates the classes and the wood specie with strength values that are useful for the design of the restoration and reinforcement project.

Thanks to the clarity of the method described in the Italian standard it is possible to cope with the great variability of wood and it is possible to apply to jack arch floors in the Valencian Community.

Figure 12.

\section{GRADING METHOD AND RESULTS}

The Italian standard UNI 11119 of 2004 have been used to grade jack arch floors on the main floors of three buildings in the Valencian Community: a mid- $19^{\text {th }}$ century building in the historic center of Valencia, a vernacular building in the village of Sesga in a mountain region called Rincón de Ademuz dated around the $20^{\text {th }}$ century and the Marquees of Benicarló's Palace located in the town of Benicarló of the second half of the $18^{\text {th }}$ century (Figure 13). 
Figure 13.

Before the on-site assessment, a detailed survey was made of the three buildings and some historical information was collected. In addition to these surveys, all the structural timber members were uniquely identified with a code that would relate the structures with the corresponding information in tables and charts facilitating the cross reference of data. The codes used for the joists comprise the story level of the building, the code of the room and a sequential number to be more intelligible.

On the one hand, these codes have been marked in the floor plans of the buildings and on the other hand a table has been prepared for each structural element in order to collect all the data gathered both for the assessment and the grading (Figure 14). On this table, the dimensions of the element, the presence and size of wood singularities and defects as well as observations and tests done on the element were measured and registered on-site. Performed tests were moisture content measurement by means of a portable hygrometer and resistographic drills to check the possible presence of inner decays (Lear, et al., 2010). The information of the tables was put together in one chart and elaborated. The result is the structural grading of each identified element according to the Italian standard and the assignation of one of the three strength classes or the denomination of "not suitable for structural use". Finally the grading was reflected on the plans of the buildings with a color code.

The result of the grading according to the Italian standard is a general uniformity in the quality of wood: none of the elements has been considered not suitable for structural use and the number of the joists graded as $3^{\text {rd }}$ class is also limited (Figure 15). This suggests that a selection process was done by the carpenters before the building process started. As the most 
limiting factor in the grading was the presence of big knots and the inclination of the grain, also the carpenters in the past could have done a rough visual selection.

Figure 14.

Figure 15.

In all three cases, samples were collected in order to determine the species of wood through microscopic identification. In the buildings in Valencia and Benicarló, all the structural elements belong to the Pinus sylvestris/nigra group of species. Considering the population of trees in the surrounding supply area, it is probable that the wood is Pinus nigra. The case of the building in Sesga is more interesting because it is a typical example of vernacular architecture in the highlands where the wood used in the construction was strictly the one accessible in the neighboring surroundings. Given that, three types of wood have been found in the structure: the first is, as in the other cases, Pinus nigra, the second is a specie of the genus Juniperus, most likely Juniperus sabina, considered its wide presence in the area, finally some joists were made of a hardwood identified as Populus sp. (Figure 16).

The different features of the three species are not entirely exploited in the structural configuration of the building; this means that there is not a clear relationship between the structural function of a member and its species. However, one peculiarity is that the Juniperus sabina elements are usually used as lintels and main beams and almost never as secondary joist (Figure 17).

Figure 16. 
Figure 17.

Regarding the assessment of the material degradation of these structures, in the case of the Marquees of Benicarló's Palace, a complete inspection was made. First the joists were visually analyzed, then resistographic drillings assessed the decay in the ends of the joists and finally the moisture content was measured to estimate the risk of proliferation of rot (Macchioni et al., 2012, pp. E42-E53). At least one resistographic drilling was made in each end of each joist as well as in the areas where the visual inspection suggested it; the increasing number, up to 10 , and location of this drillings depended on the specific degradation of the material since the objective of the drillings was precisely to assess the extent of this damage. Also the moisture content measurements were done on both ends of each joist near the walls and only near an old well more measurements were needed. The results highlighted the areas where termites had carved their channels in the past and where the infiltration from the terrace and balconies raised the moisture content in the wood (Diodato et al., 2013).

In the building in Valencia, as the electric tools were not available, only a close visual inspection was made with the help of wood awls. However analyzing the surface and ends of each joist was enough to see where a more profound exam of the elements was needed in order to achieve a more correct assessment.

\section{ISSUES RELATED TO THE GRADING AND TO POSSIBLE RESTORATION}

The grading done following the Italian standard evidenced some crucial points and specific issues regarding the conservation of jack arch floors. 
In the standard, concerning the inspection of the joists' surface, the text stresses visibility as the fundamental aspect to in order to identify defects and peculiarities that should be recognized and measured by a trained eye. In the case of jack arch floors almost half of the surface of the joists is hidden inside the structure, especially in the case of squared joists, the only surface that can be entirely studied is the intrados while the sides are only partially exposed; this is a fundamental difference with the usual structures of joists and planks where at least three sides of every structural element are visible. However visibility is not a problem for jack arched floors with round joists since most of the timber surface is uncovered and the vaults rest on the portions of circumference whose tangent have $45^{\circ}$ of inclination in the upper half of the circular cross-section.

As a direct measurement of squared joists is not possible, it is essential to take advantage of other techniques to measure the section. For example, resistographic drills can be used not only to determine the type and amount of degradation but also to directly measure the section with a good approximation. Otherwise, if no instrumental support is available, it is possible to extrapolate the joist height comparing it to the extrados of the vault and deducing the measure, nevertheless this method is not very precise because this value can vary considerably. This problem does not apply to the case of round joists as the diameter is almost always measurable.

Not being able to see the entire surface of the joists it is an issue to identify the presence and size of knots and other defects, if not to measure the deviation of the grain; however it is important to underline that the knots in the middle third of the joist's intrados are the most dangerous in the case of simply supported beams bending under an evenly distributed load as it is the case of most of the jack arch floors.

This problem is addressed in the standard specifying that, while the grading remains the same, it is compulsory to clarify in the final report if less than three faces of the joists were visible. 
This precaution implies that there is a chance that some defects could not be seen. A help in this direction can come from other non-destructive (Riggio M. et al., 2014) and semidestructive techniques (Tannert T. et al., 2014).

The second issue related to this type of assessment is that, once established the class of each element, the corresponding maximum tensions have to be assimilated into the restoration design. In the case of joists all being suitable for structural use, the lowest value would be taken into account and reinforcement would be applied to the structure as a whole. If the flooring allows it, the reinforcement should be built from the extrados of the structure, with compatible techniques such as dry systems using plywood boards connected to the joists and thus forming a new and more resistant composite section; avoiding instead reinforcements with the presence of water as concrete structures that also would add unneeded amount of weight to the structure (Tomás et al., 2015, pp. 695-700).

In contrast, if in a jack arch floor there is one or more joist not suitable for structural use, the problem that arises is much greater because the reinforcement must take into account this peculiarity.

A solution similar to the previous reinforcement could be applied taking into account a double spacing as the joist that is not suitable for structural use cannot be taken into consideration in a structural model because, even if it does not present any visible structural problem, its strength does not have the required margin of safety. Still it is more appropriate to intervene firstly on the mentioned joists consolidating them and then strengthening the entire structure to comply with the new contemporary needs.

While in the case of simple joists and planks structures it is possible to substitute a joist propping up the rest of the structure, in the case of jack arch floors this operation is more complicated: firstly because of the difficulty of shoring up the vaults, secondly because these vaults, at least in theory, rest on the joist that should be entirely substituted and finally 
because the joist is built in the structure of brick and plaster implying a difficult maneuver for the extraction of the joists. The general result of a total or even partial substitution would be the demolition of the two contiguous vaults or part of them that is the demolition of a healthy element in order to repair a damaged one.

\section{CONCLUSION REMARKS}

The jack arch floor is an extremely diffused structure with a long history in the Valencian Community that, although actually neglected, should be preserved as it is an important piece of cultural heritage. The mistreatment given to these structures could be reduced with the implantation of a widespread method to assess timber structures and, as the Spanish standards fail to do that, on-site grading and assessment according to the Italian standard can be of great help. This is a precious tool when it comes to start a restoration project because it is the only way to determine values of residual strength that can be used when designing the structural reinforcement.

After applying the Italian method to three jack arch floors it is possible to conclude that the compiled new knowledge about the structures creates some questions concerning firstly the visibility of the structure and secondly the type of intervention to perform.

In any case, the detailed assessment of the damaged areas is a fundamental starting point for the preservation of the structure in accordance with the desirable spirit of conservation.

\section{ACKNOWLEDGMENT}

The microscopic identification of the wood samples was done thanks to the instruments of the Microscopy Service of the Universitat Politècnica de València, Spain. 


\section{REFERENCES}

Delgado Martínez, M. 2003. Los alfarjes y artesonados de madera valencianos. Aspectos artísticos y constructivos, Master Thesis. Valencia: unpublished.

Diodato, M. 2015. Variaciones constructivas y formales en forjados y cubiertas. In Centro histórico de Valencia. Ocho siglos de arquitectura residencial. Edited by F. Vegas and C. Mileto. Valencia: Generalitat Valenciana.

Diodato, M., Macchioni, N., Brunetti, M., Pizzo, B., Nocetti, M., Burato, P., Sozzi, L., Pecoraro, E., Vegas López-Manzanares, F. and Mileto C. 2013. A Peculiar Spanish Timber Floor, the "Revoltón”: a Diagnostic Example at the "Palacio del Marqués de Benicarló”. In Advanced Materials Research. Vol. 778, pp 1064-1071. Switzerland: Trans Tech Publications.

Chapron, M. L. 1860. Étude sur les planchers en fer. In Nouvelle Annales de la Construction. Year 6, September.

De Arias y Scala F. 1897. Carpinteria Antigua Y Moderna. Atlas Barcelona: Juan Romá.

De Villanueva. J. 1827. Arte de albañilería. Madrid: Francisco Martinez Dávila.

Ger y Lobez F. 1898. Tratado de Construccion civil, Atlas. Badajoz: La Minerva Extremeña.

Gómez-Ferrer Lozano, M. 2002. Vocabulario de arquitectura valenciana. Siglos XV al XVI, Valencia: Ayuntamiento de Valencia.

Gómez-Ferrer Lozano, M. and Corbalán de Celis Durán, J. 2004. La casa del obispo de Tortosa, Alfonso de Aragón. Un palacio valenciano en la encrucijada entre dos siglos (XVXVI). In Ars Longa, 13. Valencia: Universitat de València. 
Lear, G., Kasal, B. and Anthony R. 2010. Resistance drilling. In In situ assessment of structural timber, State of the art report of the RILEM TC 215-AST. Edited by B. Kasal, T. Tannert. Dordrecht: Springer.

Llorente, T. 1889. Valencia, Colección «España: sus monumentos y sus artes - su naturaleza é historia», Tomo II, Barcelona: Establecimiento tipográfico-editorial de Daniel Cortezo y

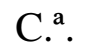

Macchioni N. 1998. Inspection techniques for ancient wooden structures. In: Structural analysis of historical constructions II: possibilities of numerical and experimental techniques. Edited by P. Roca, J.L. Gonzalez, E. Onate, P.B. Lourenco. Barcelona: CIMNE. Macchioni, N. and Piazza M. 2009. Italian standardization activity in the field of diagnosis and restoration of ancient timber structures. In Protection of historical buildings, PROHITECH 09, vol. 1-2. Edited by F.M. Mazzolani. London: Taylor \& Francis Group. pp. 349-353.

Macchioni, N., Brunetti, M., Pizzo, B., Burato, P., Nocetti, M. and Palanti S. 2012. The timber structures in the Church of the Nativity in Bethlehem: Typologies and diagnosis. In Journal of cultural heritage, Vol. 13 Issue 4 Supplement S.

Mileto, C. and Vegas F. 2008. Homo faber. Arquitectura preindustrial del Rincón de Ademuz. Casas Bajas: Mancomunidad del Rincón de Ademuz.

Nuere Matauco, E. 2000. La Carpintería de Armar Española. Madrid: Editorial Munilla Lería. Riggio M., Anthony R. W., Augelli F., Kasal B., Lechner T., Muller W. and Tannert T. 2014. In situ assessment of structural timber using non-destructive techniques. In Materials and Structures, Volume 47 Issue 5 Springe Netherlands pp. 749-766.

Tannert T., Anthony R. W., Kasal B., Kloiber M., Piazza M., Riggio M., Rinn F., Widmann R. and Yamaguchi N. 2014. In situ assessment of structural timber using semi-destructive techniques. In Materials and Structures, Volume 47 Issue 5 Springe Netherlands pp. 767-785. 
Tomás, S., Diodato, M., Vegas, F., Mileto, C. and Giménez, R. 2015. Sustainability of compression layers: timber and concrete compaired. In Vernacular Architecture, Towards a Sustainable Future. Edited by C. Mileto, F. Vegas, L. García, V. Cristini. London: CRC Press.

Vegas López-Manzanares F. and Mileto C. 2011. Aprendiendo a restaurar. Un manual de restauración de la arquitectura tradicional de la Comunidad Valenciana. Valencia: Colegio Oficial de Arquitectos de la Comunidad Valenciana.

Vegas, F., Mileto, C., Cristini, V. and Ruiz-Checa, J.R. 2013. Parameterisation of gypsum mortar for alternative structural consolidation of traditional floors. In Advances in Materials. Volumen 2-4. Science PG.

Viollet-le-Duc, E. 1854-1868. Dictionnaire raisonné de l'architecture française du XIe au XVIe siècle, Volume 7. Paris: Bance-Morel.

VV. AA. 1997. El Palau dels Centelles d'Oliva: recull gràfic i documental, Oliva: Associació Cultural Centelles i Riu-Sech. 
Figure 1.

Drawing of a jack arch floor in the Palace of the Centelles family in Oliva decorated with the representation of a military parade along the frieze (Llorente, 1889, p.708)

Figure 2.

Decorated jack arch floor over the main staircase of the Aljafería Palace in Zaragoza, 14881495. The decoration has Italian influences with alternated painted representation of yokes with gordian knots and arrows, respectively symbols of King Ferdinand II of Aragon and Queen Isabella I of Castile.

Figure 3.

Axonometric views of the different existing morphologies of jack arch floors

Figure 4.

Twisted joists used as structural element in a homestead near Elda (Alicante)

Figure 5.

Hanged false ceiling structure made with timber frames, reeds panels and a plaster finishing underneath, School of Theology, Valencia, built around 1829-1853

Figure 6.

Three examples of collapsed structures where it is possible to appreciate both the coplanar condition of the joist and vault extradoses and the reduced thickness of the floor, buildings near Cabanes (Castellón de la Plana), Albalat de la Ribera and Gandía (both Valencia)

Figure 7.

Examples of vaults: portion of a dismantled plaster conglomerate vault, pieces of bricks are visible in the section (ruins north-east of Requena, Valencia), plaster conglomerate vault with a group of reeds along the impost of the vault (homestead near Cofrentes, Valencia), jack arch floor with masonry vault and composed joists (House of the Vallier family, Valencia, building started in 1883)

Figure 8.

Decoration with the sgraffito technique (Colegio del arte mayor de la seda, Valencia, around 1756), decoration with modular plaster reliefs (Herbes Castle, Herbes, Castellon de la Plana, $15^{\text {th }}-16^{\text {th }}$ century)

Figure 9.

Drawings of jack arch floors extracted from the treaties: Arte de albañilería (de Villanueva, 1827, tab. IX, pp. 59-61), Tratado de Construccion civil (Ger y Lobez, 1898, tab. XVI) and Dictionnaire raisonné de l'architecture française du XIe au XVIe siècle (Viollet-le-Duc, 1854-1868, vol. 7, p. 205) 
Figure 10.

Degradation of the surface between the timber and the vaults caused by wood boring insects (Marquees of Benicarló’s Palace, Benicaró, Castellón de la Plana)

\section{Figure 11.}

Jack arch structure with a missing joist, the plaster vaults are still standing even with the absence of an entire joist (homestead near Cabanes, Castellón de la Plana)

Figure 12.

Table from the Italian standard UNI 11119: "Maximum tensions for the allowable stress design method and average modulus of elasticity for on-site elements made of the principal species of wood. Applicable with $12 \%$ of moisture"

Figure 13.

Façades of the studied buildings: urban building in Valencia, vernacular building in Sesga (Ademuz, Valencia), Marquees of Benicarló’s Palace (Benicarló, Castellón de la Plana)

\section{Figure 14.}

Example of a filled table with both assessment and grading information collected on-site and resulting parameters.

\section{Figure 15.}

Plans of the graded structures: Marquees of Benicarló's Palace (Benicaró, Castellón de la Plana), urban building in Valencia and vernacular building in Sesga (Ademuz, Valencia)

Figure 16.

Cross, radial and tangent sections of wood samples for the microscopic identification: Pinus sylvestris/nigra, Populus sp. and Juniperus sp. (from left to right)

Figure 17.

Plan of the species of wood used in the vernacular building in Sesga (Ademuz, Valencia) 


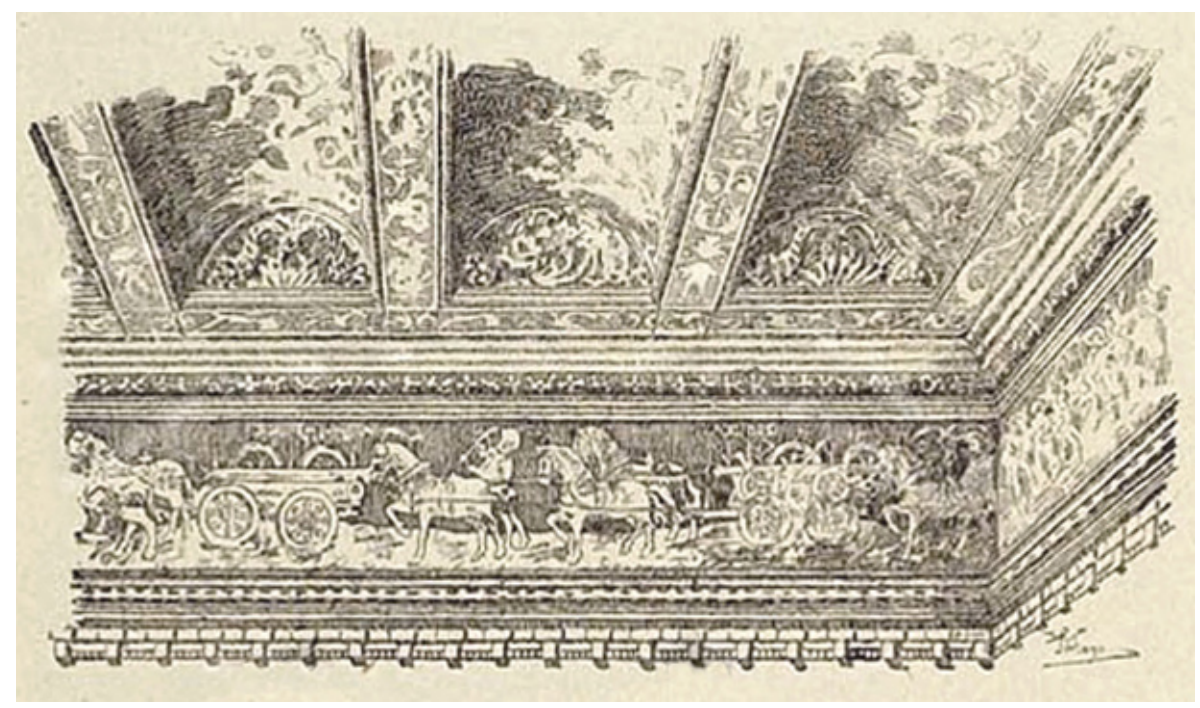

\section{Figure 1.}

Drawing of a jack arch floor in the Palace of the Centelles family in Oliva decorated with the representation of a military parade along the frieze (Llorente, 1889, p.708) 


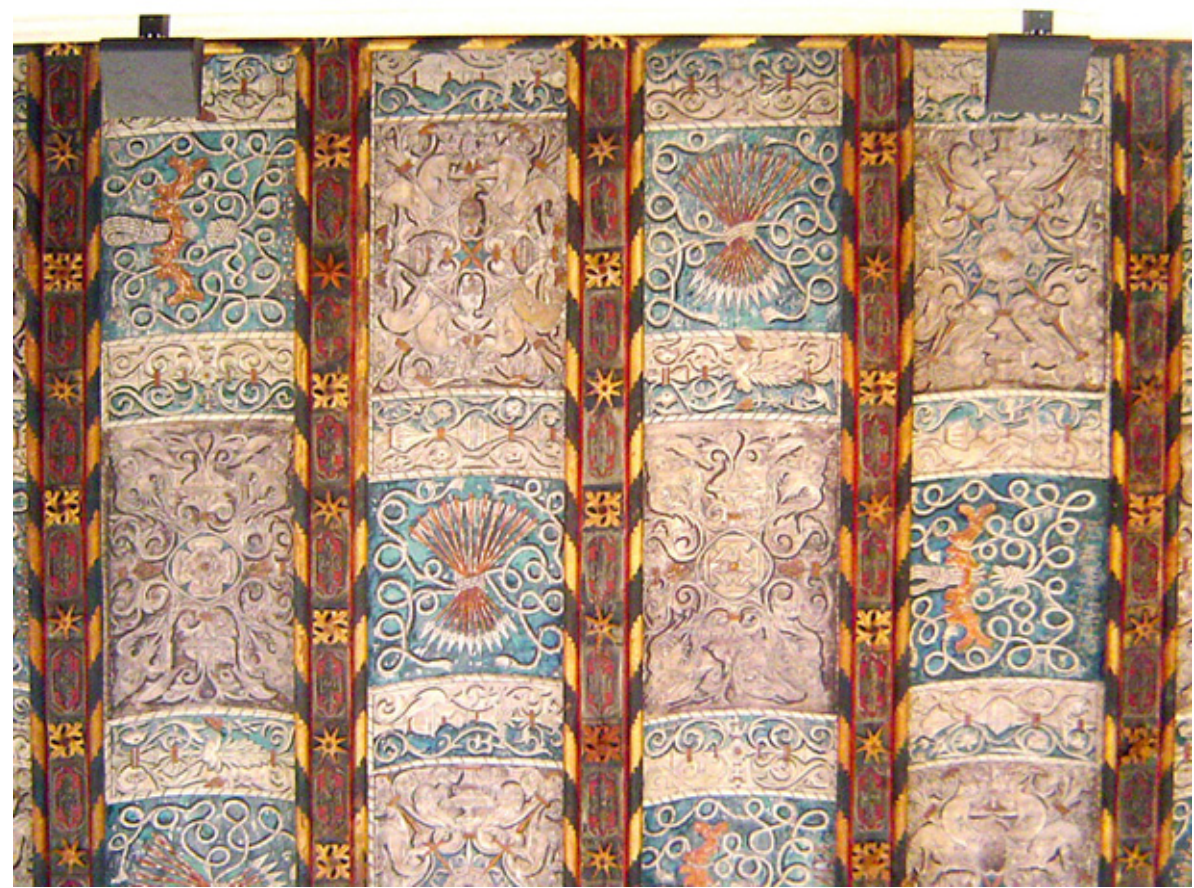

Figure 2.

Decorated jack arch floor over the main staircase of the Aljafería Palace in Zaragoza, 14881495. The decoration has Italian influences with alternated painted representation of yokes with gordian knots and arrows, respectively symbols of King Ferdinand II of Aragon and Queen Isabella I of Castile. 


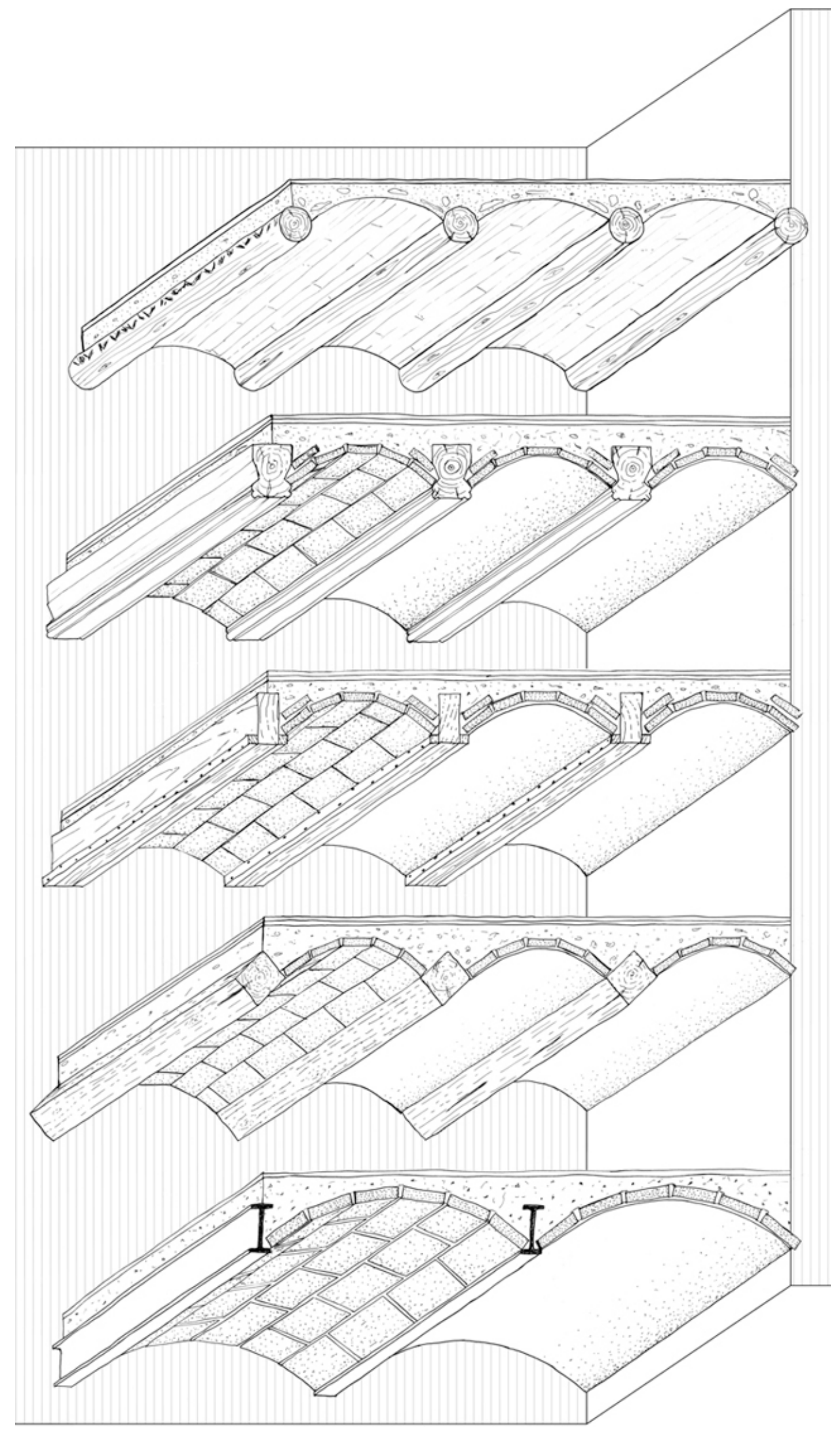

Figure 3.

Axonometric views of the different existing morphologies of jack arch floors 


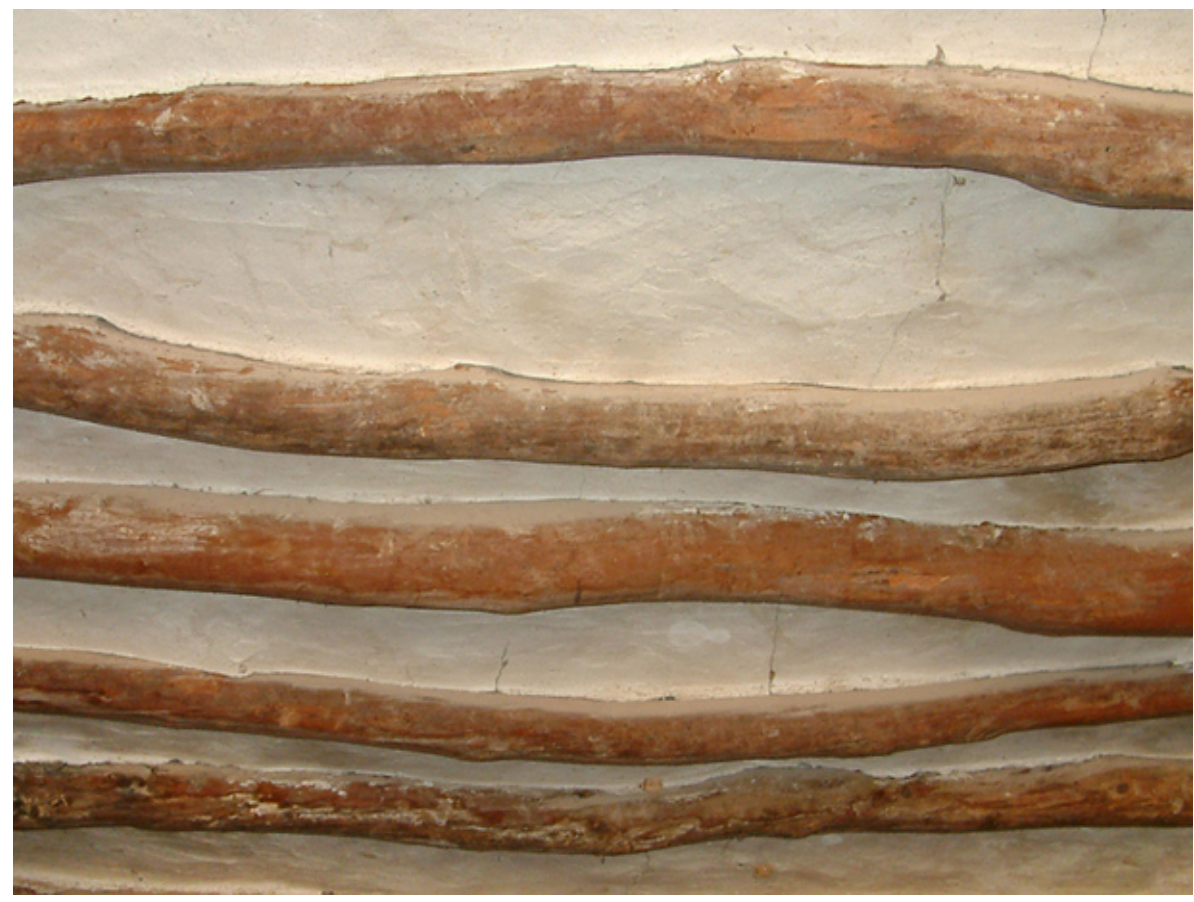

Figure 4.

Twisted joists used as structural element in a homestead near Elda (Alicante) 


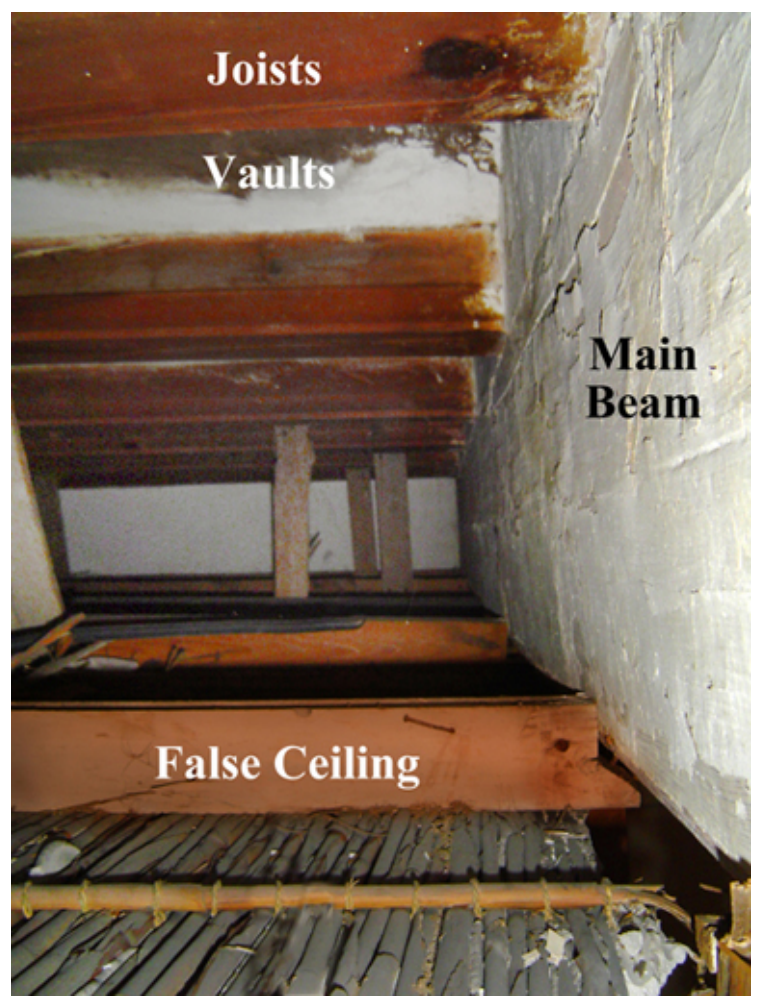

\section{Figure 5.}

Hanged false ceiling structure made with timber frames, reeds panels and a plaster finishing underneath, School of Theology, Valencia, built around 1829-1853 

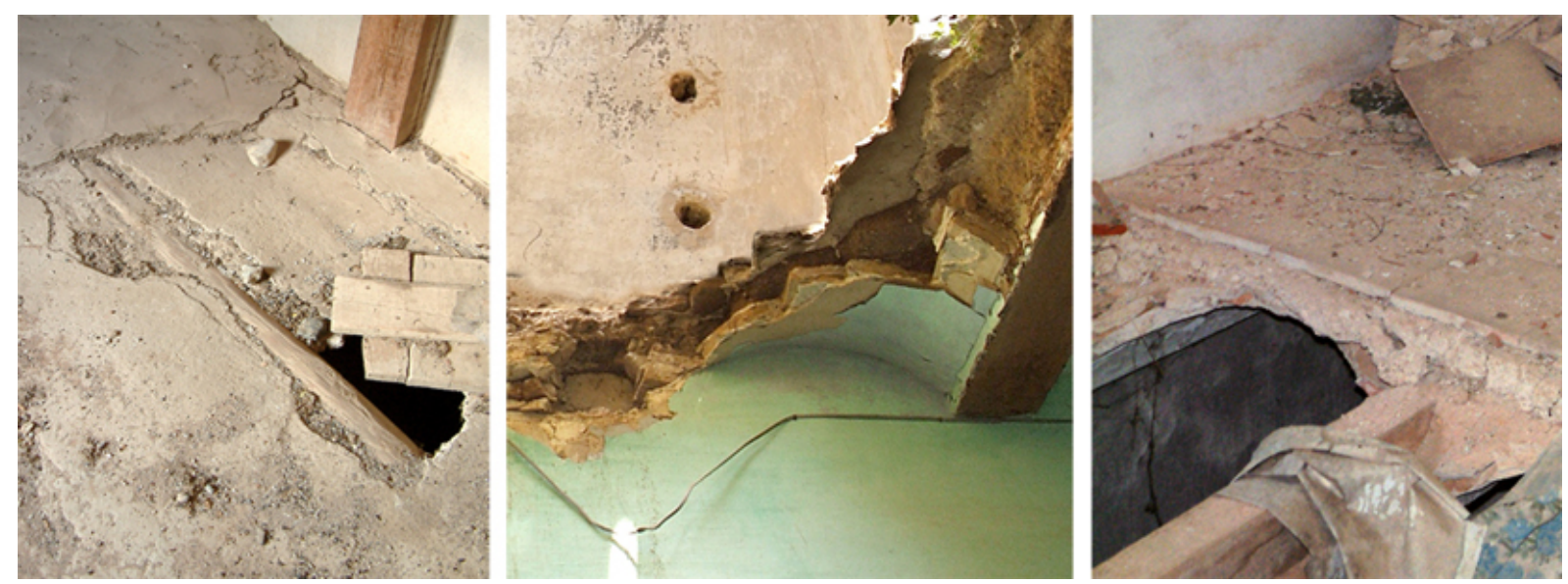

\section{Figure 6.}

Three examples of collapsed structures where it is possible to appreciate both the coplanar condition of the joist and vault extradoses and the reduced thickness of the floor; buildings near Cabanes (Castellón de la Plana), Albalat de la Ribera and Gandía (both Valencia) 

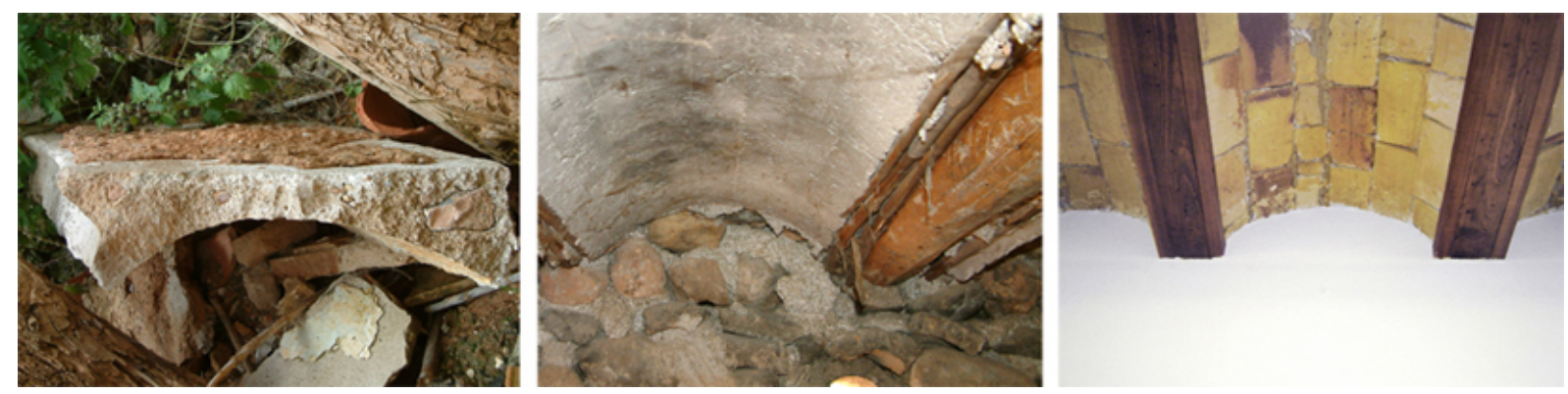

\section{Figure 7.}

Examples of vaults: portion of a dismantled plaster conglomerate vault, pieces of bricks are visible in the section (ruins north-east of Requena, Valencia), plaster conglomerate vault with a group of reeds along the impost of the vault (homestead near Cofrentes, Valencia), jack arch floor with masonry vault and composed joists (House of the Vallier family, Valencia, building started in 1883) 

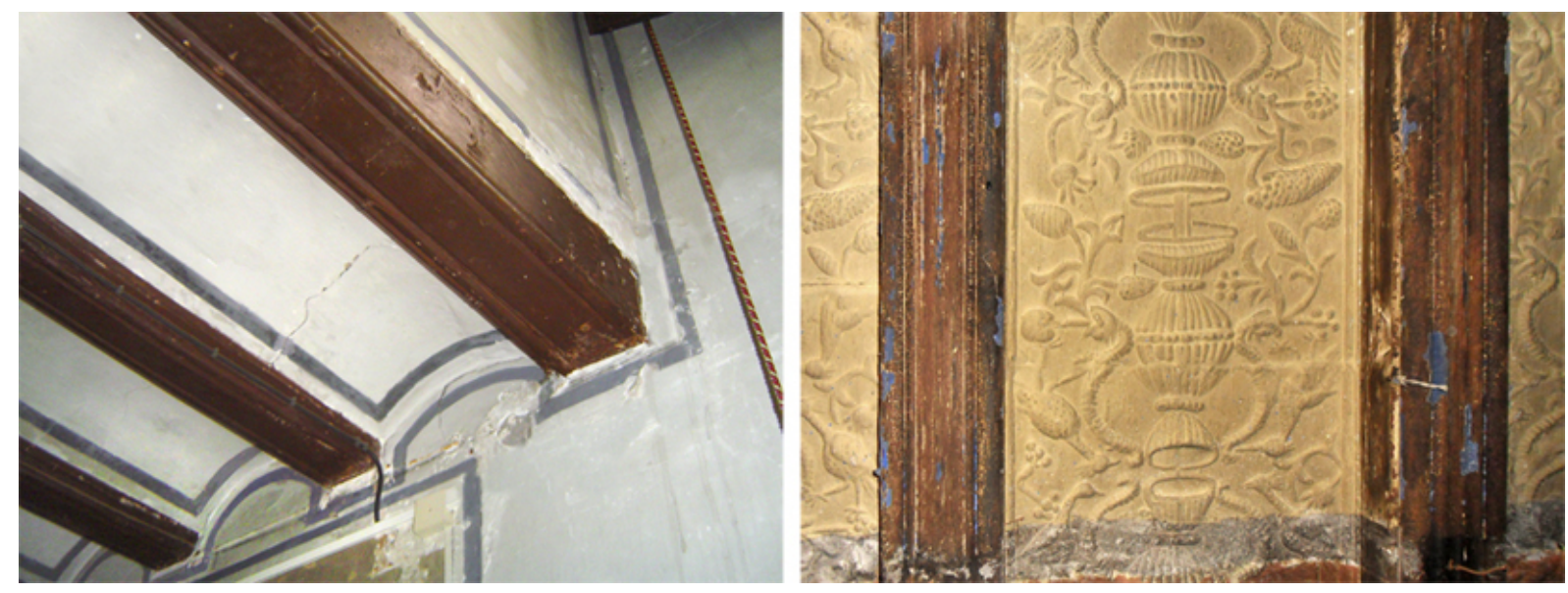

Figure 8.

Decoration with the sgraffito technique (Colegio del arte mayor de la seda, Valencia, around 1756), decoration with modular plaster reliefs (Herbes Castle, Herbes, Castellon de la Plana, $15^{\text {th }}-16^{\text {th }}$ century) 

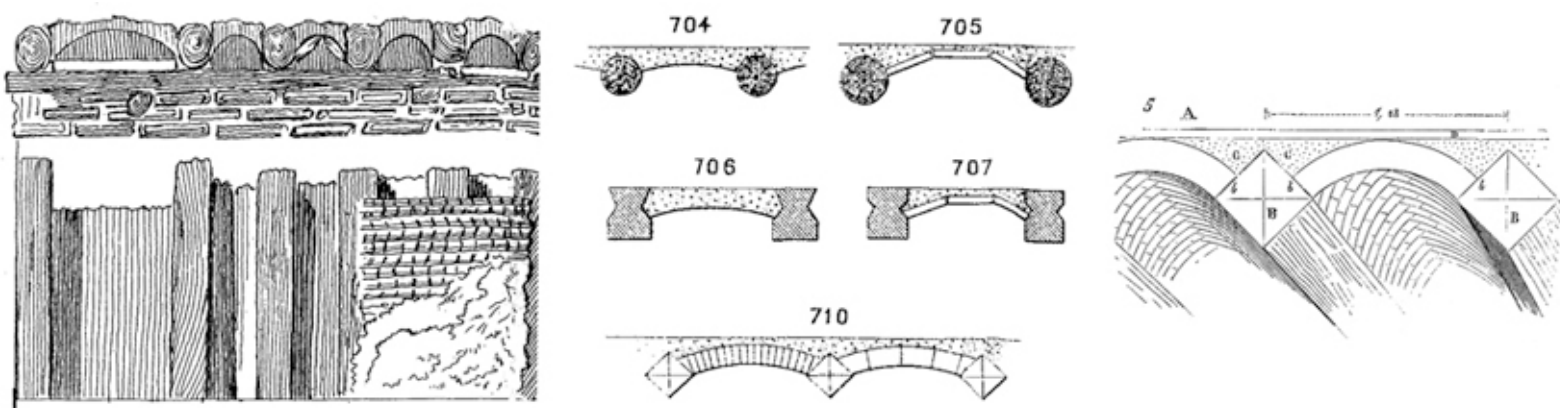

\section{Figure 9.}

Drawings of jack arch floors extracted from the treaties: Arte de albañilería (de Villanueva, 1827, tab. IX, pp. 59-61), Tratado de Construccion civil (Ger y Lobez, 1898, tab. XVI) and Dictionnaire raisonné de l'architecture française du XIe au XVIe siècle (Viollet-le-Duc, 1854-1868, vol. 7, p. 205) 


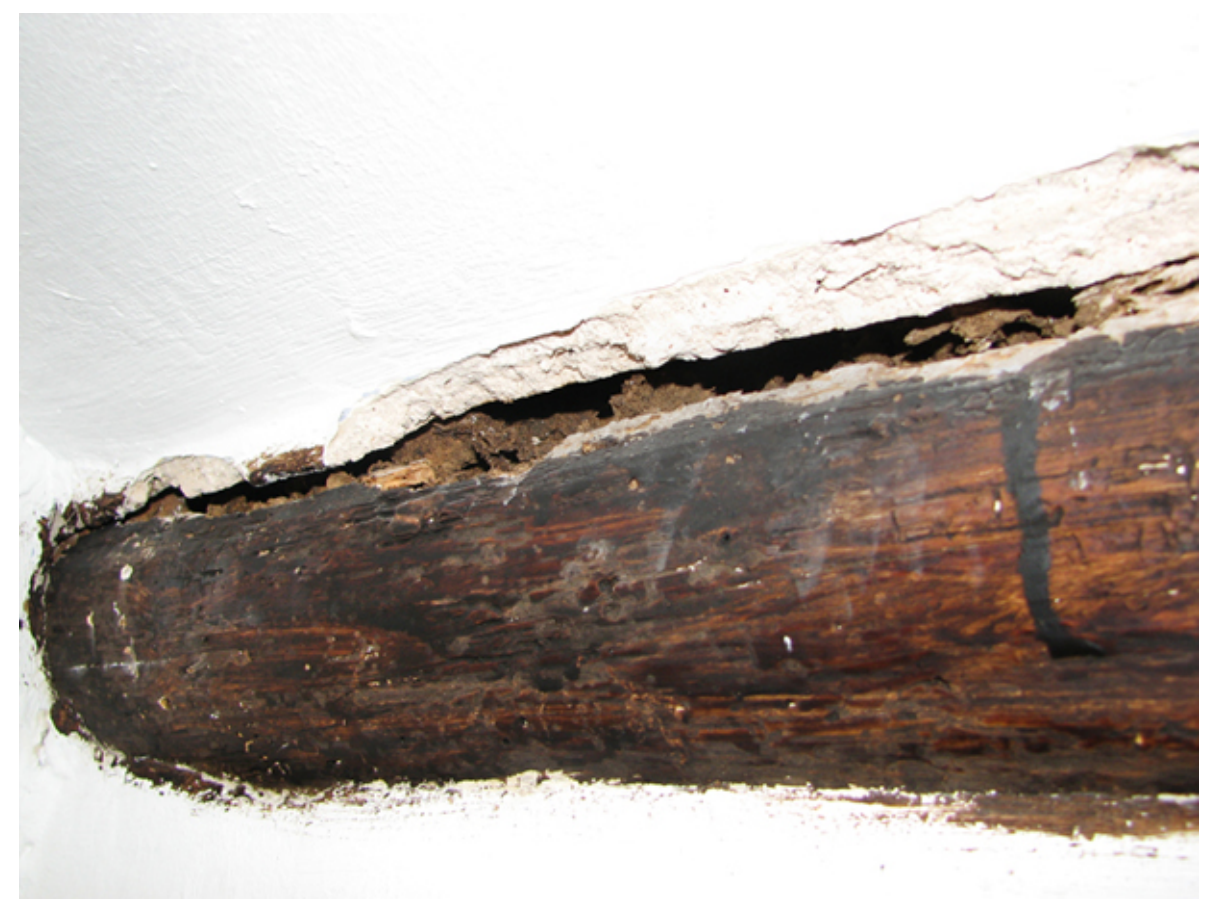

Figure 10.

Degradation of the surface between the timber and the vaults caused by wood boring insects (Marquees of Benicarló’s Palace, Benicaró, Castellón de la Plana) 


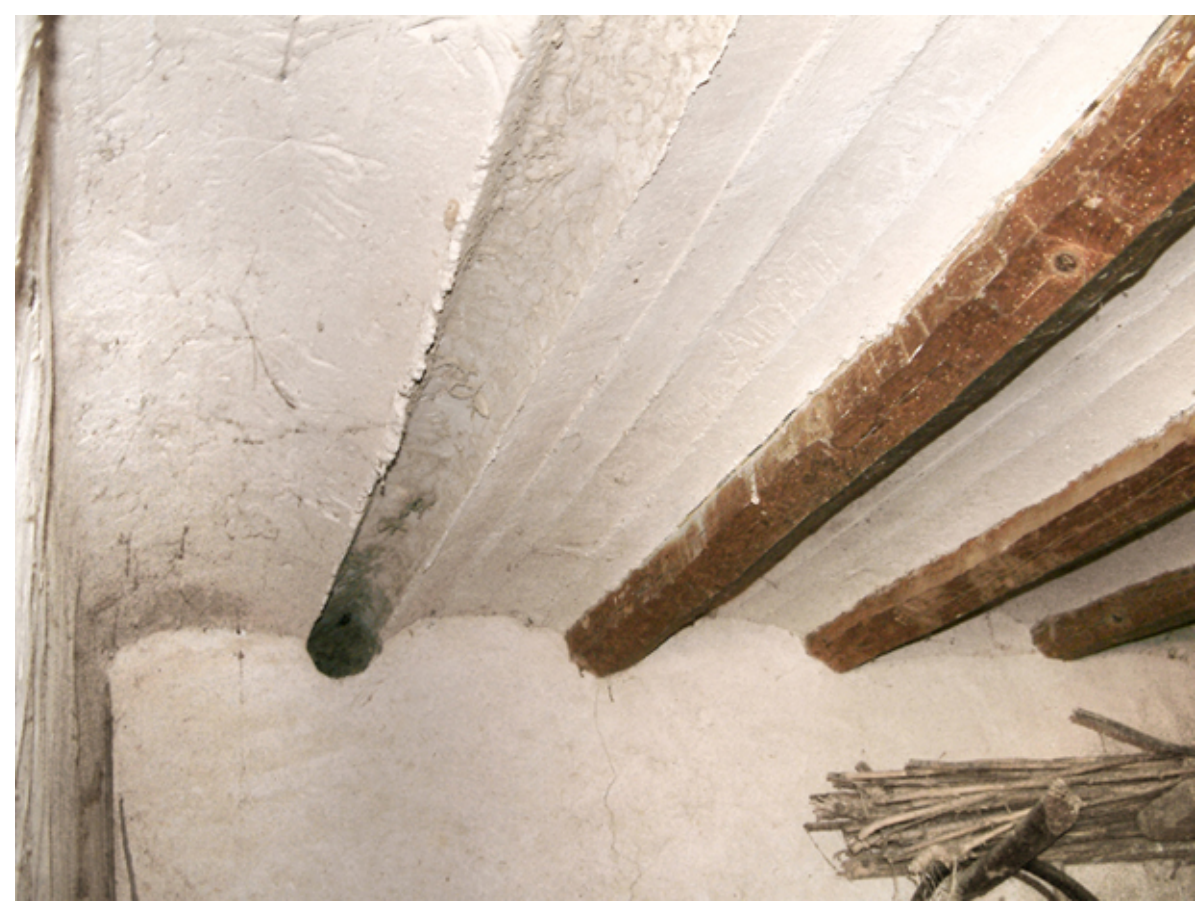

Figure 11.

Jack arch structure with a missing joist, the plaster vaults are still standing even with the absence of an entire joist (homestead near Cabanes, Castellón de la Plana) 


\begin{tabular}{|c|c|c|c|c|c|c|c|}
\hline \multirow[b]{3}{*}{ Species } & \multirow{3}{*}{$\begin{array}{c}\text { Category } \\
\text { of the } \\
\text { on-site } \\
\text { element }\end{array}$} & \multicolumn{6}{|c|}{ Maximum tensions $\left[\mathrm{N} / \mathrm{mm}^{2}\right]$} \\
\hline & & \multicolumn{2}{|c|}{ Compression } & \multirow[b]{2}{*}{$\begin{array}{l}\text { Static } \\
\text { flexion }\end{array}$} & \multirow{2}{*}{$\begin{array}{l}\text { Tension } \\
\text { parallel } \\
\text { to the } \\
\text { fibre }^{1)}\end{array}$} & \multirow{2}{*}{$\begin{array}{l}\text { Shear } \\
\text { parallel } \\
\text { to the } \\
\text { fibre }\end{array}$} & \multirow{2}{*}{$\begin{array}{c}\text { Flexion } \\
\text { modulus } \\
\text { of } \\
\text { elasticity }\end{array}$} \\
\hline & & $\begin{array}{l}\text { Parallel to } \\
\text { the fibre }\end{array}$ & $\begin{array}{l}\text { Perpendicular } \\
\text { to the fibre }\end{array}$ & & & & \\
\hline \multirow{3}{*}{$\begin{array}{l}\text { Silver Fir } \\
\text { (Abies alba Mill.) }\end{array}$} & I & 11 & 2,0 & 11,5 & 11 & 0,9 & 13000 \\
\hline & II & 9 & 2,0 & 10 & 9 & 0,8 & 12000 \\
\hline & III & 7 & 2,0 & 7,5 & 6 & 0,7 & 11000 \\
\hline \multirow{3}{*}{$\begin{array}{l}\text { Norwey Spruce } \\
\text { (Picea abies Karst.) }\end{array}$} & $\mathrm{I}$ & 10 & 2,0 & 11 & 11 & 1,0 & 12500 \\
\hline & II & 8 & 2,0 & 9 & 9 & 0,9 & 11500 \\
\hline & III & 6 & 2,0 & 7 & 6 & 0,8 & 10500 \\
\hline \multirow{3}{*}{$\begin{array}{l}\text { Larch } \\
\text { (Larix spp.) }\end{array}$} & I & 12 & 2,5 & 13 & 12 & 1,1 & 15500 \\
\hline & II & 10 & 2,2 & 11 & 9,5 & 1,0 & 14500 \\
\hline & III & 7,5 & 2,0 & 8,5 & 7 & 0,9 & 13500 \\
\hline \multirow{3}{*}{$\begin{array}{l}\text { Pines } \\
\text { (Pinus spp.) }\end{array}$} & I & 11 & 2,0 & 12 & 11 & 1,0 & 13000 \\
\hline & II & 8 & 2,0 & 10 & 9 & 0,9 & 12000 \\
\hline & III & 7 & 2,0 & 8 & 6 & 0,8 & 11000 \\
\hline \multirow{3}{*}{$\begin{array}{l}\text { Chestnut } \\
\text { (Castanea sativa } \text { Mill.) }\end{array}$} & I & 11 & 2,0 & 12 & 11 & 0,8 & 10000 \\
\hline & II & 9 & 2,0 & 10 & 9 & 0,7 & 9000 \\
\hline & III & 7 & 2,0 & 8 & 6 & 0,6 & 8000 \\
\hline \multirow{3}{*}{$\begin{array}{l}\text { Poplar } \\
\text { (Populus spp.) }\end{array}$} & I & 10 & 1,5 & 10,5 & 9 & 0,6 & 9000 \\
\hline & II & 8 & 1,5 & 8,5 & 7 & 0,5 & 8000 \\
\hline & III & 6 & 1,5 & 6,5 & 4,5 & 0,4 & 7000 \\
\hline \multirow{3}{*}{$\begin{array}{l}\text { Oak } \\
\text { (Quercus spp.) }\end{array}$} & I & 12 & 3,0 & 13 & 12 & 1,2 & 13500 \\
\hline & II & 10 & 2,5 & 11 & 10 & 1,0 & 12500 \\
\hline & III & 7,5 & 2,2 & 8,5 & 7 & 0,9 & 11500 \\
\hline
\end{tabular}

1) Traction perpendicular to the fibre is supposed to be equal to zero.

Figure 12.

Table from the Italian standard UNI 11119: "Maximum tensions for the allowable stress design method and average modulus of elasticity for on-site elements made of the principal species of wood. Applicable with $12 \%$ of moisture" 



Figure 13.

Façades of the studied buildings: urban building in Valencia, vernacular building in Sesga (Ademuz, Valencia), Marquees of Benicarló’s Palace (Benicarló, Castellón de la Plana) 


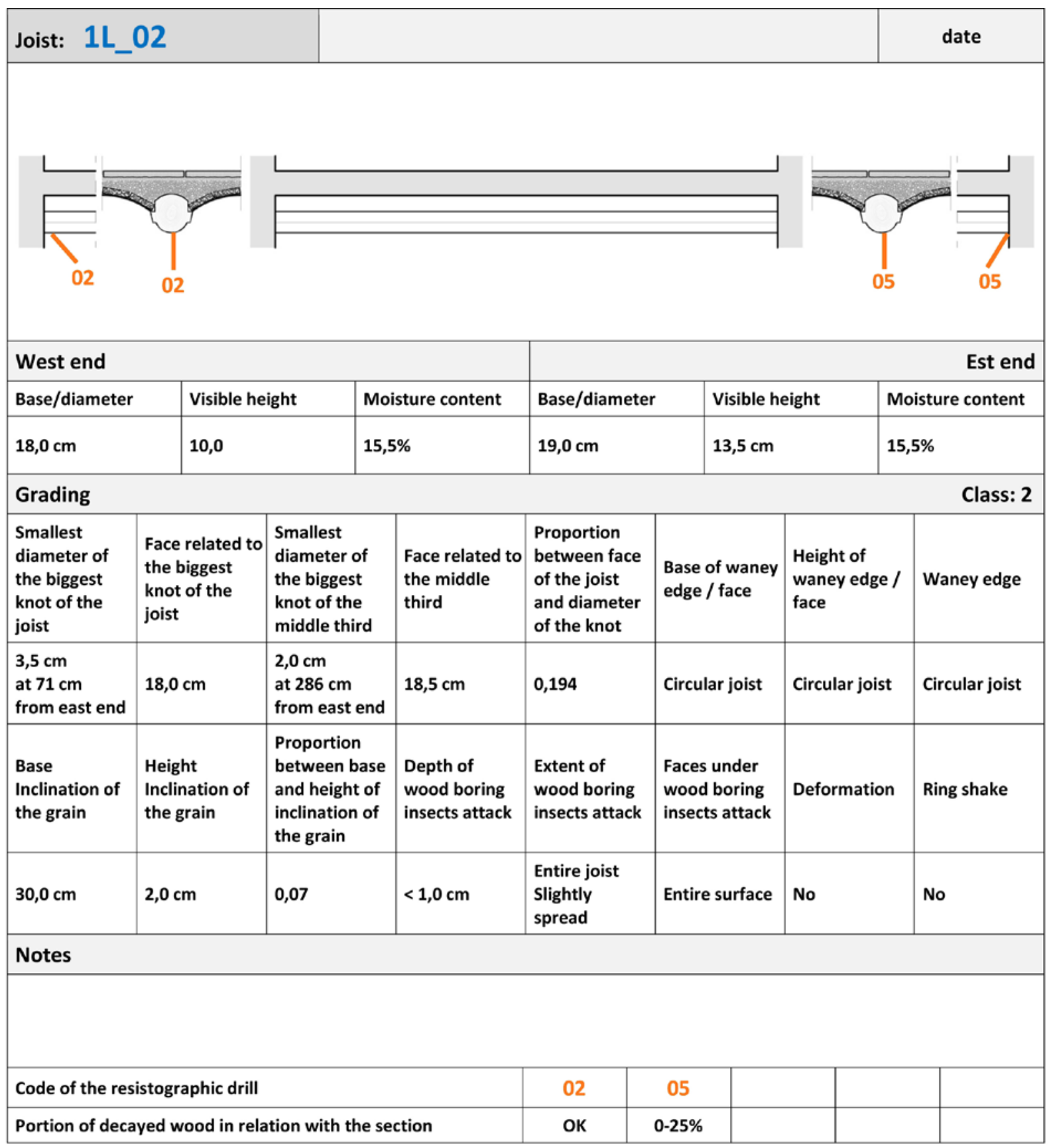

Figure 14.

Example of a filled table with both assessment and grading information collected on-site and resulting parameters. 



Class 1

- Class 2

- Class 3

* Not suitable for

Not surveyed

Figure 15.

Plans of the graded structures: Marquees of Benicarló's Palace (Benicaró, Castellón de la Plana), urban building in Valencia and vernacular building in Sesga (Ademuz, Valencia) 

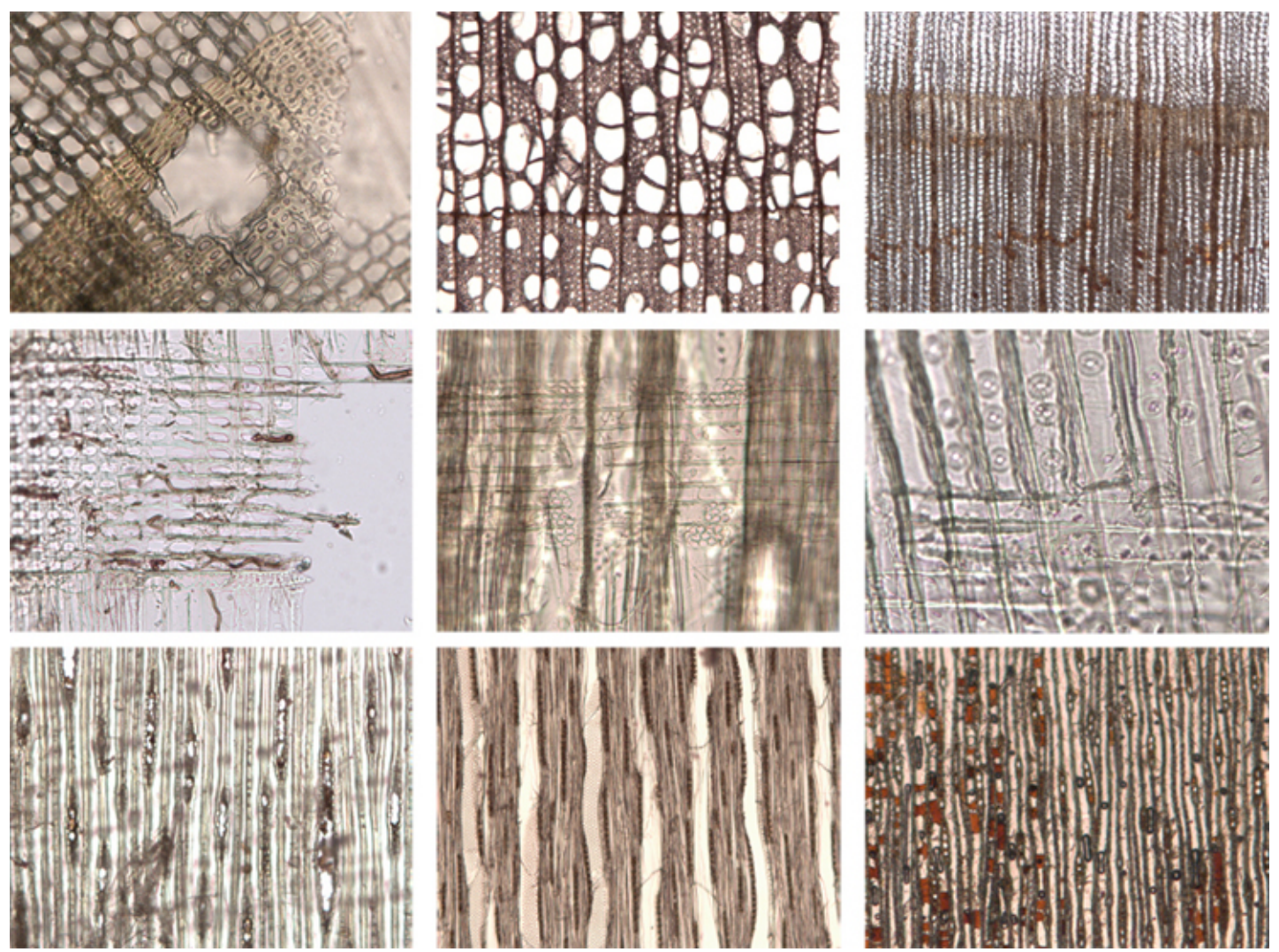

Figure 16.

Cross, radial and tangent sections of wood samples for the microscopic identification: Pinus sylvestris/nigra, Populus sp. and Juniperus sp. (from left to right) 


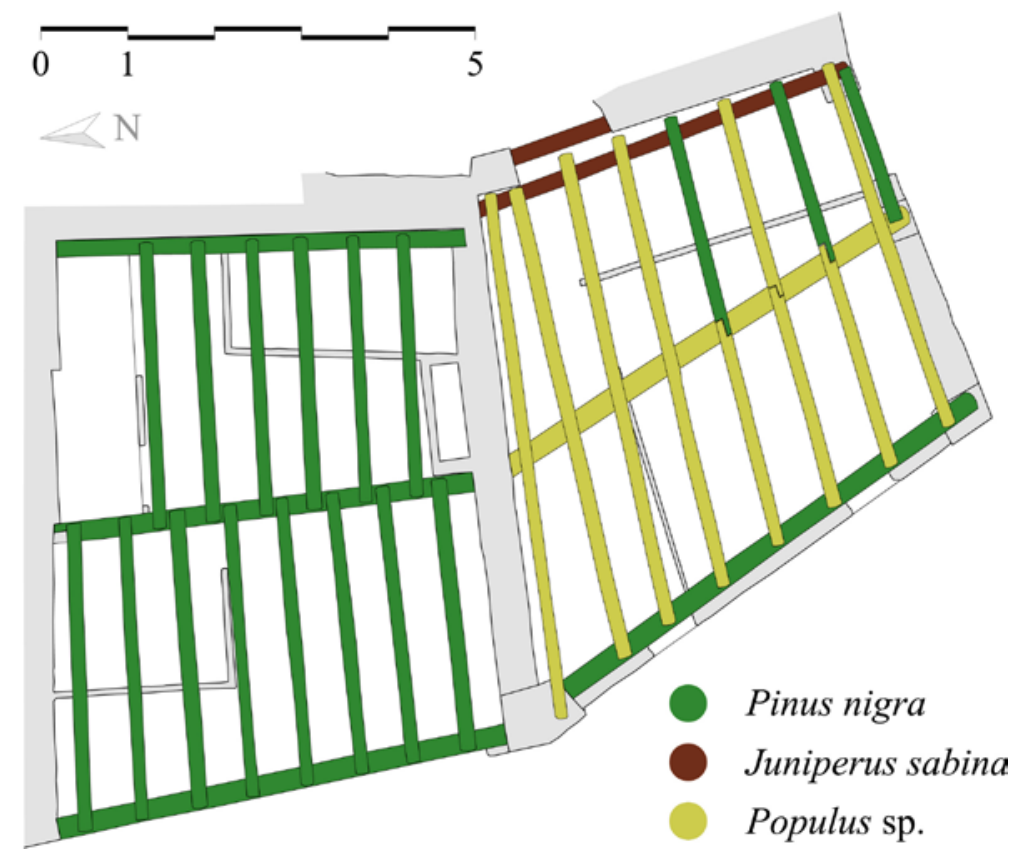

Figure 17.

Plan of the species of wood used in the vernacular building in Sesga (Ademuz, Valencia) 